\title{
Simulation of Loads on the Carrying Structure of an Articulated Flat Car in Combined Transportation
}

\author{
Alyona Lovska ${ }^{1} *$ \\ ${ }^{1}$ Ukrainian State University of Railway Transport \\ *Corresponding author E-mail:alyonalovskaya.vagons@gmail.com
}

\begin{abstract}
The article presents the findings of the research into loading on the carrying structure of an articulated flat car under combined transportation. The refined data of dynamic loads on the carrying structure of a flat car under train ferry transportation, as well as the main loading modes in rail track operation were determined by mathematical modeling. The adequacy of the models developed was checked with an F-test. The results of the calculation conducted made it possible to conclude that the hypothesis on adequacy of the models is not rejected. The peculiarities of the structural strength modeling for a flat car within operational loading diagrams are given. The graphics works were conducted in Solid Works. The capacity analysis was conducted by the finite element method in CosmosWorks. The 09G2S steel was used as a construction material. It is determined that the maximum equivalent loads in the flat car support structure do not exceed the admissible loads. Results of the research can be used in designing coupled flat cars to provide their capacity at mixed transportation.
\end{abstract}

Keywords: Articulated Flat car; Carrying Structure; Combined Transportation; Dynamics; Strength.

\section{Introduction}

Development of the competitive environment in the rail transportation market with its higher efficiency requires the introduction of the new generation rolling stock along with combined transportation systems [1-3]; and train ferry transportation is one of the most promising. It can be describes as possibility to transport cars by sea with specially equipped vessels - train ferries.

An insufficient level of the car fleet renewal on Ukrainian railways requires introduction of new engineering solutions regarding improved carrying structures of car bodies intended for transporting specific types of freight.

Train ferry transportation is characterized by high loads on carrying structures which exceed the loads in rail track transportation. It can damage the structural elements intended for their fixation relative to the deck.

In order to provide stable fixation of cars on train ferries it is necessary to improve their carrying structures, as well as, at the development stage, to consider refined data of loading on them in train ferry transportation.

\section{Literature Survey}

Definition of capacity indexes of a flat car for transporting containers and loading/unloading works is conducted with the system ACTS in [4]. And the capacity calculation at a static mode was conducted under Nastran software. The numerical data of the designed loads on a flat car were taken in accordance with the PNEN12663 and BN - 77/3532 - 40 standards. The capacity of a flat car was calculated with consideration of four load diagrams on its structure:

- compressive force of $2 \mathrm{MN}$ along the buffer axle;
- compressive loads of $0.4 \mathrm{MN}$ along the diagonal at the level of the buffers;

- tensile loads of $1 \mathrm{MN}$ along the buffer axles;

- vertical inertia loads on the carrying structure of a flat car taking into account an acceleration of $1.95 \mathrm{~g}$.

The structural features of a flat car for intermodal transportation are considered in [5]. The general requirements for the intermodal transportation organization, as well as the advantages of this transportation were described. It should be mentioned that the problem of dynamic loads on the carrying structures of car bodies in train ferry transportation was not considered in these studies.

The features of development of a high-speed articulated flat car for container transportation are given in [6]. The engineering solutions taken during the flat car designing made it possible to transport simultaneously two $40-\mathrm{ft}$ or $45-\mathrm{ft}$ containers or four $20-\mathrm{ft}$ containers.

The capacity modeling of the flat car frame with a motor semitrailer on is conducted in [7]. The study proposes a design diagram which allows obtaining refined stress values for the carrying structure of a flat car.

The studies do not give consideration to the investigation into the flat car dynamics in rail operation.

The research into loading and reliability of rail cars with the methods of dynamics for a body system is presented in [8]. The technique considered was used in the research of dynamic loading and fatigue resistance of the long-base flat car frame intended for container transportation. The analysis of a new generation flat car structure is given in [9]. A special feature of a flat car is the possibility to adjust an effective length according to dimensions of the freight transported.

Study [10] substantiates the efficiency to use flat cars in container transportation, for example, tank containers built at Transmash 
(Russia). The flat car structure capacity is 73 tons; and 1CC, 1C and 1CX containers can be transported.

The research into the dynamics of a rail car with the open charge level is given in [11]. The calculation was made in MSC Adams software. And the research into the flat car tip stability was conducted while running on a $250-\mathrm{m}$ radius curve with consideration of various traffic speeds.

But the studies do not touch upon the problem of the capacity modeling of the flat car carrying structure.

\section{Methodology}

In order to improve the efficiency of combined transportation along international transport corridors the study proposes the articulated flat car structure based on a typical model (Fig. 1).

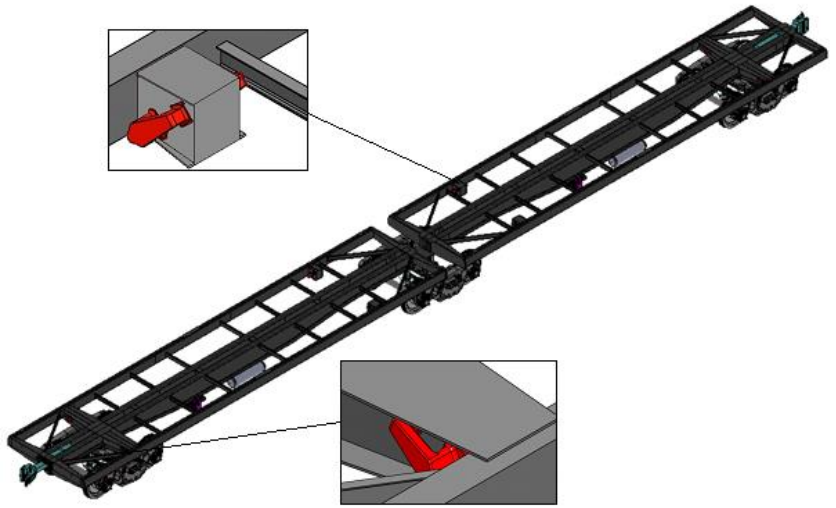

Fig. 1: Articulated flat car

In order to transport articulated flat cars by train ferry the author proposes to mount fixing units for chain binders on the carrying structure [12]. The fixing units are mounted on the body bolster beams of a flat car (Fig. 1), thereby providing the spatial layout of the chain binders and conformity of the slope angles to the normative documents. On the side where the sections are rested on the middle bogie the fixing units are installed on the box superstructure.

The accelerations, as components of dynamic loads on the carrying structure of an articulated flat car with containers on in train ferry transportation, were defined with mathematical models developed in accordance with Lagrange equations of the $2^{\text {nd }}$ type which consider the following vibrations [13, 14]:

1) without displacements of a flat car and containers relative to the initial position under the train ferry vibrations (Fig. 2, A);

2) with displacements of a flat car due to train ferry vibrations when the containers are immovable relative to the flat car frame (Fig. 2, B);

3) with displacements of the flat car relative to the deck and the containers relative to the flat car frame (Fig. 2, C).

The angle displacements of a flat car with containers along the longitudinal axle $X$ to the angle $\theta$ (the equivalent of vibrations is the rolling in the car dynamics) were taken into consideration, as the case of the maximum loading on the carrying structures of a flat car with containers, as well as stability relative to the deck.

The calculations were done for the train ferry "Heroi Shipki" operating in the Black Sea. It was considered that the flat car was loaded with $1 \mathrm{CC}$ containers, and its gross weight was 24 tons.

The impact action of sea waves to the train ferry body with cars on was not considered. While designing the model the trochoidal law of disturbing action (sea waves) to the train ferry with containers on and the dissipative component occurring due to train ferry vibrations in sea rolling, as well as the relative bearings of sea waves to the train ferry body and the wind force to the abovewater view of the train ferry, flat car on the upper deck and containers were considered.
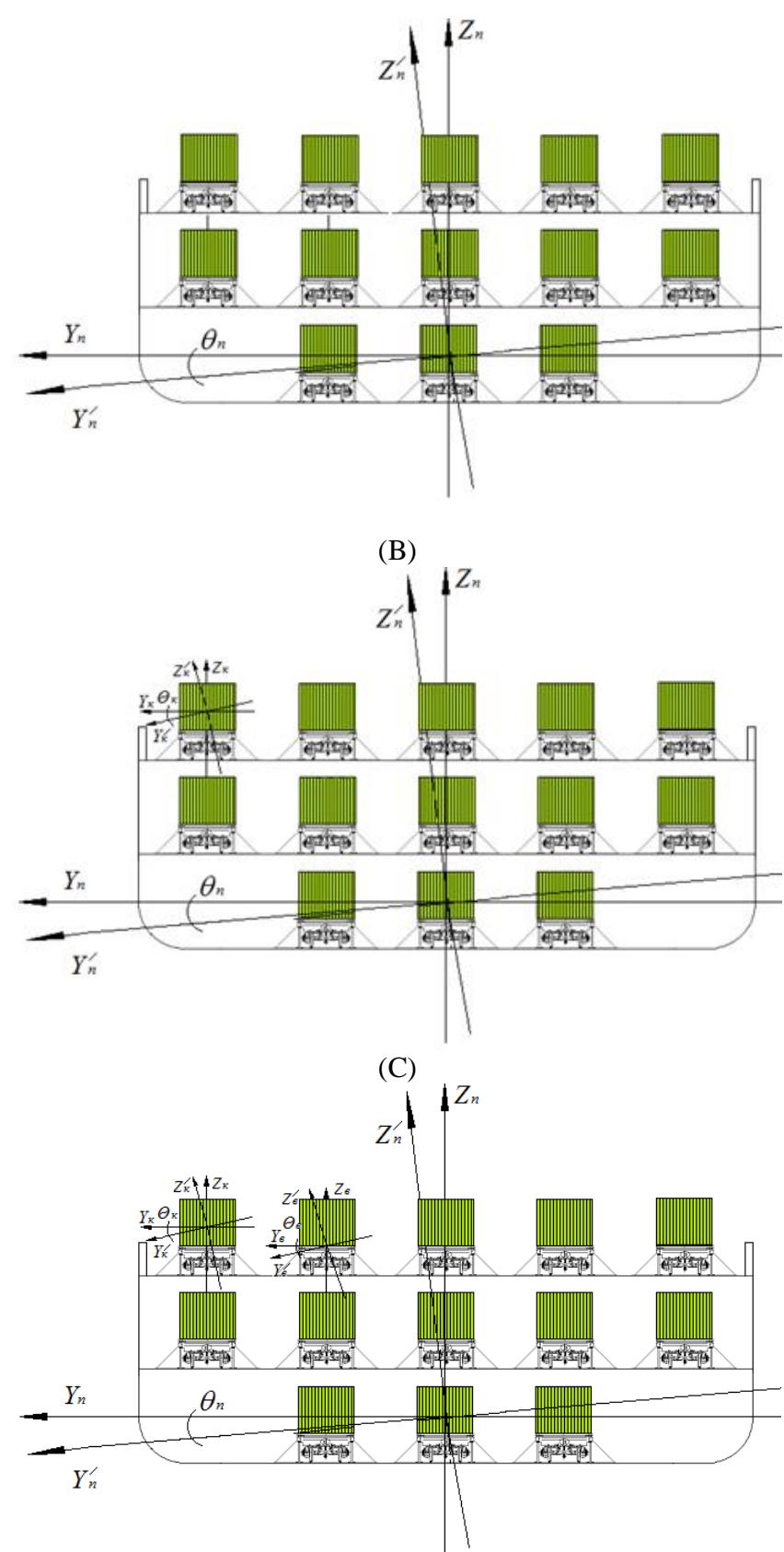

Fig. 2: Design diagram for research into angle displacements relative to the longitudinal axle of a train ferry loaded with flat cars with containers on; (A) without displacement of a flat car with containers relative to the deck; (B) with displacements of a flat car relative to the deck and without displacements of containers relative to a flat car; (C) with displacements of a flat car relative to the deck and containers relative to the flat car

Displacements of the flat car and containers relative to the initial position considering the rigid fixation relative to the deck (Fig. 2, A) due to train ferry vibrations are described by the equation

$\left(\frac{D}{12 \cdot g}\left(B^{2}+4 z_{g}^{2}\right)\right) \ddot{q}+\left(\Lambda_{\theta} \cdot \frac{B}{2}\right) \dot{q}=p^{\prime} \cdot \frac{h}{2}+\Lambda_{\theta} \cdot \frac{B}{2} \cdot \dot{F}(t)$

where $q=\theta$ is the generalized coordinate corresponding to the angle displacement along the longitudinal axle. The origin of coordinates is located in the center of mass of the train ferry; $D$ is the weight displacement; $B$ is the width of the train ferry; $h$ is the deck height of the train ferry; $\Lambda_{\theta}$ is the coefficient of vibration resistance; $z_{g}$ is the position of the train ferry's mass center; $p^{\prime}$ is the wind load; $F(t)$ is the law of action of the force which causes the train ferry with cars on to move.

The initial displacements and the train ferry speed were taken equal to zero. 
The input parameters of the mathematic model are geometric characteristics of the train ferry, hydro meteorological characteristics of the Black Sea waters, and coordinates to set the car relative to the center of train ferry vibrations.

The differential equation was solved with a program created in Mathcad [15, 16], where it was reduced to a regular Cauchy problem with consequent integration by the Runge-Kutta method.

Fig. 3 presents the accelerations on the carrying structure of a flat car with containers located on the outer (from the bulwark) track of the upper deck of the train ferry under angle displacements along the longitudinal axle. The highest acceleration occurs at a relative bearings to the train ferry body of $\chi=120^{\circ}$.

The acceleration values given do not consider the horizontal component of the free fall acceleration.

The general acceleration on the outer (from the bulwark) flat car with containers was about $0.25 \mathrm{~g}$.

In order to define accelerations on the flat car with containers in train ferry transportation with consideration of possible displacements of the car relative to the deck under unsafe sea conditions (Fig. 2, B) a mathematical model was designed (2).

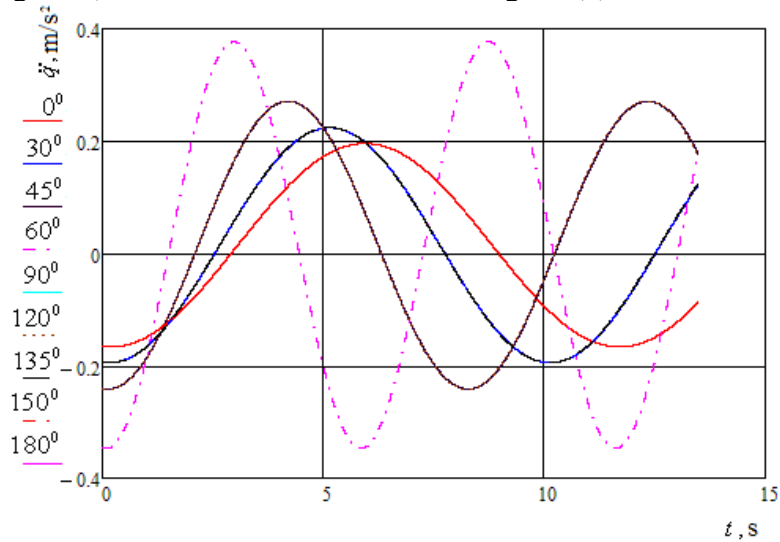

Fig. 3: Accelerations on the carrying structure of a flat car with containers due to train ferry vibrations

The first equation of the mathematical model describes the train ferry displacements due to the sea waves, and the second one describes displacements of the flat car with containers relative to the deck.

The mathematical model considered the level of freedom of the flat car relative to the deck; it can be specified by:

- deck irregularity;

- possible deviations in the frame geometry;

- non- symmetry in terms of the flat car fixation, etc.

$$
\left\{\begin{array}{l}
\left(\frac{D}{12 \cdot g}\left(B^{2}+4 z_{g}{ }^{2}\right)\right) \ddot{q}_{1}+\left(\Lambda_{\theta} \cdot \frac{B}{2}\right) \dot{q}_{1}=p^{\prime} \cdot \frac{h}{2}+\Lambda_{\theta} \cdot \frac{B}{2} \cdot \dot{F}(t) \\
I_{\theta}^{F L W} \cdot \ddot{q}_{2}=p_{F L W}^{\prime} \cdot \frac{h_{F L W}}{2}+M_{F L W}^{D}
\end{array}\right.
$$

where $q_{1}=\theta_{1}$ is the generalized coordinate corresponding to the angle displacement of the train ferry along the longitudinal axle; $q_{2}=\theta_{2}$ is the generalized coordinate corresponding to the angle displacement of a flat car with containers along the longitudinal axle. The origin of the coordinate system is in the center of mass of the train ferry; $I_{\theta}^{F L W}$ is the inertia moment of the flat car with containers along the longitudinal axle; $p_{F L W}^{\prime}$ is the wind load to the side projection of the flat car with containers on the upper deck of the train ferry; $h_{F L W}$ is the height of the side projection of the flat car with containers; $M_{F L W}^{D}$ is the moment of forces occurring between the flat car and the deck of the train ferry under angle displacements along the longitudinal axle.

The initial displacement and speed of the train ferry were taken as equal to zero, for the flat car with containers the initial displace- ment was determined by possible flexibility of its units relative to the deck (the axle-box unit along the wheelset axle, the bogie frame along the box unit axle, the friction wedge relative to the center of the side axle, the body central bearing relative to the friction wedge, the body central bearing along the axial bearing [17]) and was $31 \mathrm{~mm}$. The initial speed was taken as zero.

The mathematical model designed did not consider the impact force from the sea waves to the body of the train ferry with cars on.

The results of the calculations are given in Fig. 4. The general value of acceleration on the outer (from the bulwark) flat car with containers was about $0.3 \mathrm{~g}$.

The results obtained made it possible to conclude that the given value of acceleration exceeded the acceleration on the container located on the flat car with consideration of the rigid fixation to the deck by almost $20 \%$.

For determination of accelerations when the flat car moved relative to the deck and containers moved relative to the flat car frame a mathematical model was built; it took into account the angle displacements of the system elements (train ferry - flat car - container) about the longitudinal axle (Fig. 2, C).

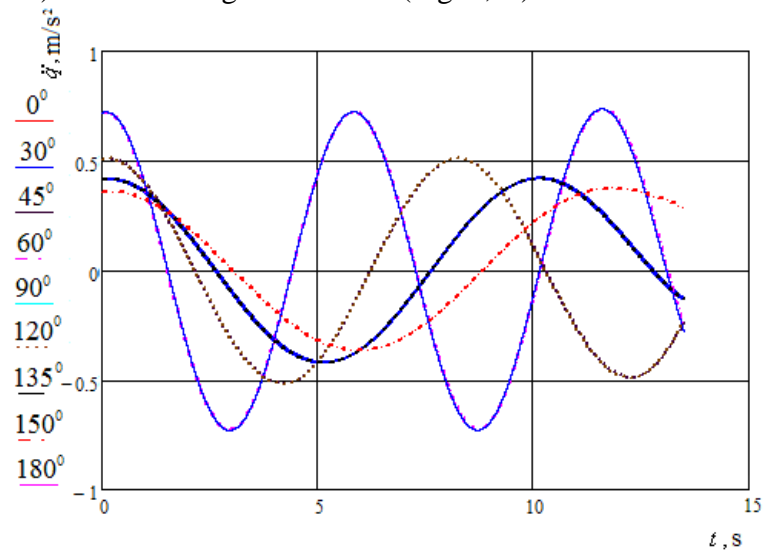

Fig. 4: Accelerations on the carrying structure of a flat car with containers in train ferry transportation with consideration of possible displacements relative to the deck

$$
\left\{\begin{array}{l}
\left(\frac{D}{12 \cdot g}\left(B^{2}+4 z_{g}^{2}\right)\right) \ddot{q}_{1}+\left(\Lambda_{\theta} \cdot \frac{B}{2}\right) \dot{q}_{1}=p_{3 I}^{\prime} \cdot \frac{h}{2}+ \\
+\Lambda_{\theta} \cdot \frac{B}{2} \cdot \dot{F}(t) \\
I_{F L W}^{\theta} \cdot \ddot{q}_{2}=p_{F L W}^{\prime} \cdot \frac{h_{F L W}}{2}+M_{F L W}^{D}+M_{F L W}^{c} \\
I_{C}^{\theta} \cdot \ddot{q}_{3}=p_{C}^{\prime} \cdot \frac{h_{K}}{2}+M_{C}^{F L W}
\end{array}\right.
$$

where $q_{1}=\theta_{1}$ is the generalized coordinate corresponding to the angle displacement about the longitudinal axle of the train ferry; $q_{2}=\theta_{2}$ is the generalized coordinate corresponding to the angle displacement about the longitudinal axle of a flat car; $q_{3}=\theta_{3}$ is the generalized coordinate corresponding to the angle displacement about the longitudinal axle of the container. The origin of the coordinates system is in the center of mass of a train ferry; $M_{F L W}^{C}$ is the moment of forces occurring between a flat car and containers under angle displacements relative to the longitudinal axle; $I_{C}^{\theta}$ is the inertia moment of a container; $h_{c}$ is the height of a container side surface; $p_{c}^{\prime}$ is the wind load on the container side surface; $M_{C}^{F L W}$ is the moment of forces occurring between the container and the flat car under angle displacements relative to the longitudinal axle.

While defining the moment of forces between the flat car and the deck the longitudinal component of the gross weight with consideration of friction forces between the components of the car were 
taken into account. While defining the moment of forces between the flat car and container, the horizontal component of the gross weight of the container, friction forces between the fitting stop and fitting, as well as the fitting stop geometry were taken into account.

It was assumed that the flat car under angle displacements about the longitudinal axle had its own level of freedom up to the moment, when friction force $F_{F R}$ took values lower than dynamic load $P_{d}$, whereby the body moved at the value of possible horizontal shifts of the structural elements [17] and reiterated the movement pattern of the train ferry. In order to consider it, the following assumption was accepted in the mathematical model: if $t=n$ then $q_{2}=q_{1}$, where $n$ is the moment of time, when $F_{F R}<P_{d}$. The same was true about the container, possible displacements of which were explained by a technological gap between the fitting stop and fitting. Thus, the flat car had its own level of freedom limited by the value of possible shifts of structural elements; thereafter it repeated the movement pattern of the train ferry. The container had its own level of freedom up to the moment when the vertical side of the fitting rested on the fitting stop.

Based on the calculations conducted, it was proved that the highest values of accelerations occurred when the relative bearing of the sea waves to the train ferry body were $\chi=60^{\circ}$ and $\chi=120^{\circ}$. The results of the calculations are given in Fig. 5.

And the maximum accelerations of the container were about $2.5 \mathrm{~m} / \mathrm{s}^{2}$, the flat car $-1.8 \mathrm{~m} / \mathrm{s}^{2}$ (Fig. 5).

Numerical values of accelerations are given without the free fall component.

It was established that without displacements of the flat car and containers relative to the initial position the general value of the acceleration impacting the outer (from the bulwark) flat car with containers was about $0.25 \mathrm{~g}$.

And when the flat car was displaced due to train ferry vibrations and the containers were immobile relative to the frame, the general value of the acceleration was about $0.3 \mathrm{~g}$.

With displacements of a flat car relative to the deck and containers relative to the flat car frame the general value of the acceleration influencing the outer (from the bulwark) flat car was about $0.4 \mathrm{~g}$, and that on the containers located on it was about $0.47 \mathrm{~g}$.

The results obtained make it possible to conclude that the given value of acceleration exceeds the acceleration on the container placed on the flat car, with consideration of rigid fixation relative to the deck, by about $50 \%$, and with displacements of the flat car relative to the deck and without displacements of containers relative to the frame by $35 \%$.

In order to assess the container stability relative to the flat car frame the research into the equilibrium stability coefficient $k_{s}$ at angular displacements of the train ferry relative to the longitudinal axis was conducted (Fig. 6).

In order to provide the equilibrium stability of the container relative to the flat car frame the following condition is to be met [13, 14]:

$$
k_{c}=\frac{M_{R}}{M_{o}} \geq 1
$$

where $M_{R}$ is the value of restoring moment; $M_{O}$ is the value of overturning moment.

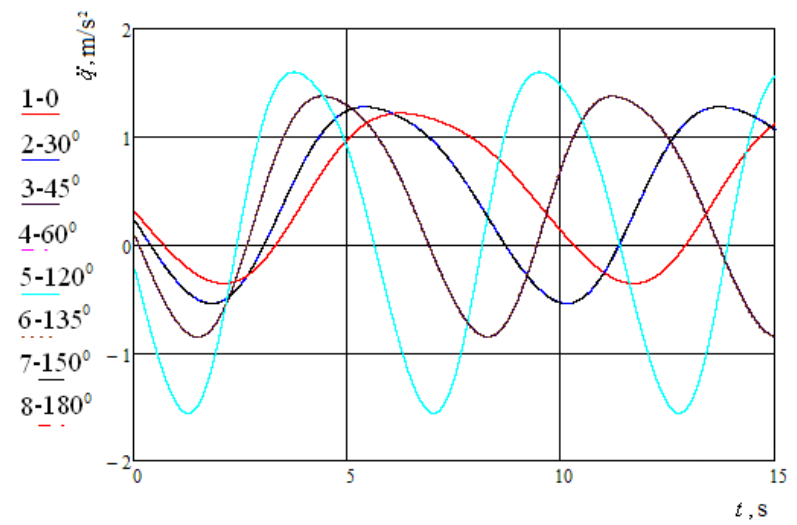

(B)

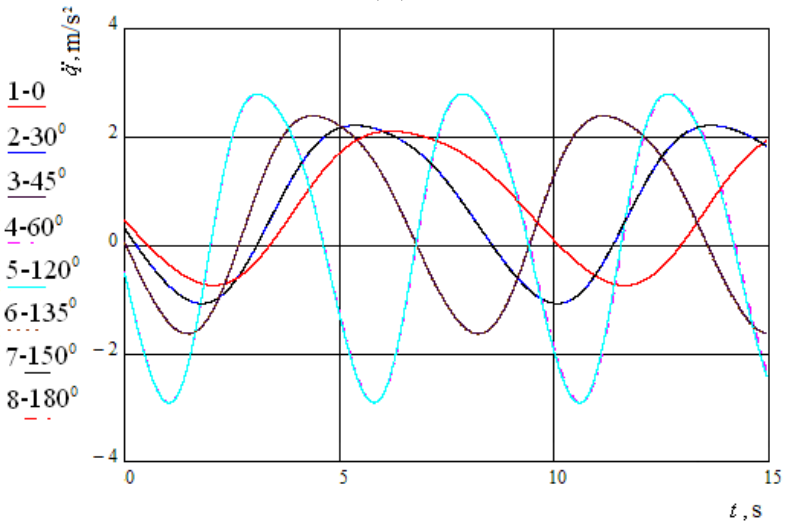

Fig. 5: Accelerations on the carrying structure of a flat car with containers under train ferry transportation with consideration of possible displacements relative to the initial position; (A) flat car; (B) container

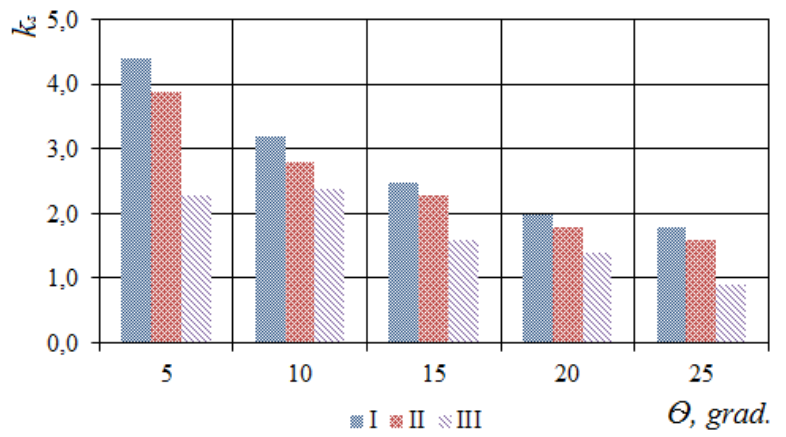

Fig. 6: Dependency of the container stability coefficient relative to the flat car frame on the tilt angle of the train ferry

$$
\begin{aligned}
& M_{R}=p_{C}^{\prime} \cdot \frac{h_{C}}{2}+M_{g m} \cdot\left(g \cdot \sin \theta+\ddot{q}_{C}\right) \cdot \frac{h_{C}}{2} \\
& M_{o}=P_{g w} \cdot \cos \theta \cdot \frac{B_{C}}{2}+n_{f} \cdot\left(M_{g m} \cdot\left(g \cdot \sin \theta+\ddot{q}_{C}\right)\right) \cdot \frac{h_{f}}{2}
\end{aligned}
$$

where $M_{g m}$ is the gross mass of the container; $\ddot{q}_{c}$ is the acceleration on the container at angle displacements relative to the longitudinal axle; $P_{g w}$ is the gross weight of the container; $B_{C}$ is the width of the container; $n_{f}$ is the number of fitting stops the container is rested on under angle displacements relative to the longitudinal axle, $h_{f}$ is the height of the fitting stop.

While defining the overturning moment the maximum numerical values of accelerations were taken into consideration; they were calculated with mathematical modeling (1-3) and are components of the dynamic loads impacting the container. The stability threshold was established when the values of restoring and overturning moments were equal.

The conducted research made it possible to conclude that the stability coefficient of the container relative to the flat car frame was 
less than 1 with displacements of container's fittings relative to fitting stops of the flat car. And the container stability was provided at the rolling angles of the train ferry up to $25^{\circ}$.

Besides, the research into the dynamic loads impacting the carrying structure of an articulated flat car under train ferry transportation was conducted with computer modeling by applying the finite element method in CosmosWorks.

The adequacy of the models developed was checked with an Ftest. The results of the calculation conducted made it possible to conclude that the hypothesis on adequacy of the models is not rejected.

The findings obtained were used for calculation of the carrying structure stability of an articulated flat car under train ferry transportation. The calculation was made with the finite element method in CosmosWorks. It was taken into account that the flat car carrying structure is effected by the vertical loads in zones where containers rest on the fitting stops $P_{f}^{v}$, and also by the forces from the chain binders on the fixing units relative to the deck $P_{f i x}$ (Fig. 7). As far as the chain binder was of a spatial layout, the forces from it to the flat car carrying structure were divided into three components (Table 1).

The model was fixed in areas where the carrying structure rested on the bogies. The modeling of support of the carrying structure on working surfaces of mechanical jacks the round pads of the diameter equal to the diameter of the working part of the jack were mounted.

In order to determine the optimal number of elements in the grid the graphic-analytical method was applied. The number of nodes in the grid was 148723, and elements - 462131. The maximum size of the element was $200 \mathrm{~mm}$, the minimal $-40 \mathrm{~mm}$. The minimal number of elements in the circle was 9 , correlations of element expansion in the grid was 1.7. The maximum correlation of the sides was 6182.6, the percentage with the correlation of the sides lower than 3 was 13.4, and more than 10 were 33.7 .

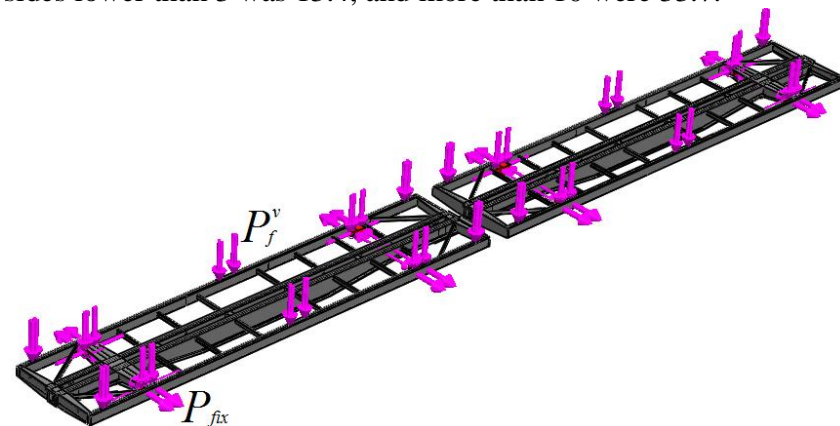

Fig. 7: Stability model of an improved carrying structure of an articulated flat car with fixing units on the train ferry deck

The $09 \Gamma 2 \mathrm{C}$ steel of the capacity limit $\sigma_{C}=490 \mathrm{MPa}$ and the fluidity limit $\sigma_{F}=345 \mathrm{MPa}$ were taken as the material for the flat car carrying structure.

Table 1: Loads on the carrying structure of an articulated flat car through the chain binders

\begin{tabular}{|l|c|c|c|}
\hline \multirow{2}{*}{ Displacement type } & \multicolumn{3}{|c|}{ Force value, $\mathrm{kN}$} \\
\cline { 2 - 4 } & $P_{x}$ & $P_{y}$ & $P_{z}$ \\
\hline $\begin{array}{l}\text { Angle displacements relative to } \\
\text { the longitudinal axle }\end{array}$ & 92.94 & 129.96 & 160.98 \\
\hline
\end{tabular}

The results of the calculation of the flat car carrying structure are given in Fig. 8.

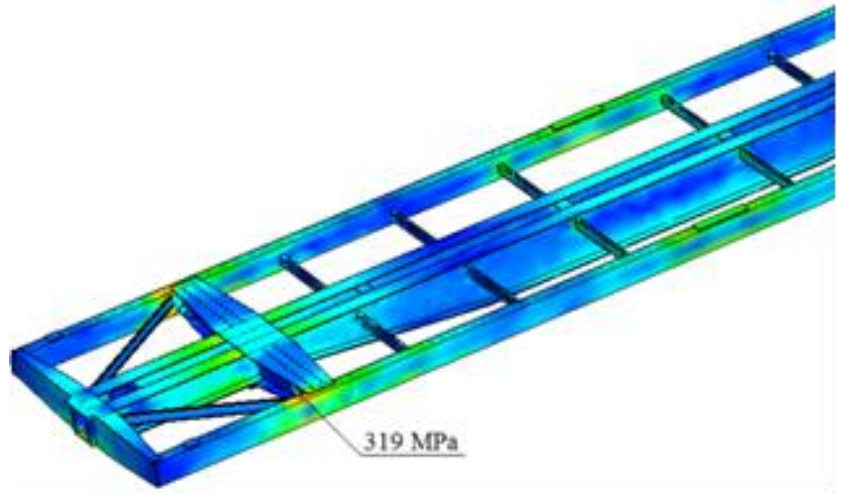

Fig. 8: Stress state of the improved carrying structure of an articulated flat car at angle displacements of a train ferry relative to the longitudinal axle

The research conducted make it possible to conclude that the maximum equivalent of stresses in the flat car carrying structure are concentrated in the zone of interaction between the bolster beam and the main longitudinal axle and accounts for $320 \mathrm{MPa}$, that is, they do not exceed the admissible stresses for the steel grade of the metal frame [18]. The maximum displacements were $33.4 \mathrm{~mm}$, and deformations $-3,78 \cdot 10^{-2}$.

The modal analysis of the articulated flat car carrying structure under train ferry transportation demonstrated that numerical values of the critical frequencies of vibrations are within the admissible limits.

The research into the dynamic loads on the articulated flat car was also conducted at the basic loading modes on rail tracks. The research was based on the mathematical model from [19] wherein the accelerations of a tank container, placed on a flat car and effected by the longitudinal force from the hammer car were defined.

In order to define accelerations of the flat car carrying structure, as a dynamic loading component, the model was improved by taking into account displacements of two sections of the flat car under operational loading modes. Besides, it eliminated the spring links between the containers and flat car carrying structure due to a shorter section, based on a typical 13-401 flat car, in comparison with a long-base flat car, the dynamics of which was investigated in [19]. The pattern of the longitudinal force on the articulated flat car with containers on without possible displacements of fittings relative to fitting stops is given in Fig. 9.

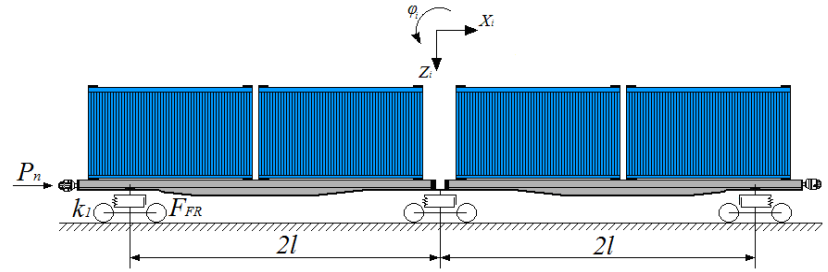

Fig. 9: Pattern of the longitudinal force on the articulated flat car with containers on

$M_{F L_{1}}^{\prime} \cdot\left(\ddot{x}_{F L_{1}}-\ddot{x}_{F L_{2}}\right)+M_{F L_{1}} \cdot h \cdot \ddot{\varphi}_{F L_{1}}=P_{n}$

$I_{F L_{1}} \cdot \ddot{\varphi}_{F L_{1}}+M_{F L_{1}} \cdot h \cdot\left(\ddot{x}_{F L_{1}}-\ddot{x}_{F L_{2}}\right)-g \cdot \varphi_{F L_{4}} \cdot M_{F L_{4}} \cdot h=$

$=l \cdot F_{F R}\left(\operatorname{sign} \dot{\Delta}^{F L_{1}}-\operatorname{sign} \dot{\Delta}_{2}^{F L_{1}}\right)+l\left(k_{1} \cdot \dot{4}^{F L}-k_{2} \cdot \dot{\Delta}_{2}^{F L}\right)$

$M_{F L_{1}} \cdot \ddot{z}_{F L_{1}}=k_{1} \cdot \Delta^{F L_{1}}+k_{2} \cdot \Delta_{2}^{F L_{1}}-F_{F R}\left(\operatorname{sign} \dot{\Delta}^{F L_{1}}-\operatorname{sign} \dot{\Delta}_{2}^{F L_{1}}\right)$

$m_{i} \cdot\left(\ddot{x}_{F L_{1}}-\ddot{x}_{F L}\right)+\left(m_{i} \cdot z_{c i}\right) \cdot \ddot{\varphi}_{F L_{1}}=0$

$I_{i} \cdot \ddot{\varphi}_{F L_{1}}+\left(m_{i} \cdot z_{c i}\right) \cdot\left(\ddot{x}_{F L_{1}}-\ddot{x}_{F L_{2}}\right)-g \cdot\left(m_{i} \cdot z_{c i}\right) \cdot \varphi_{F L_{1}}=0$ 
$m_{i} \cdot \ddot{z}_{F L_{1}}=0$

$M_{F L_{2}}^{\prime} \cdot\left(\ddot{x}_{F L_{1}}-\ddot{x}_{F L_{2}}\right)+M_{F L_{2}} \cdot h \cdot \ddot{\varphi}_{F L_{2}}=0$

$I_{F L_{2}} \cdot \ddot{\varphi}_{F L_{2}}+M_{F L_{2}} \cdot h \cdot\left(\ddot{x}_{F L_{1}}-\ddot{x}_{F L_{2}}\right)-g \cdot \varphi_{F L_{2}} \cdot M_{F L_{2}} \cdot h=$

$=l \cdot F_{F R}\left(\operatorname{sign} \dot{4}^{F L_{2}}-\operatorname{sign} \dot{\Delta}_{2}^{F L_{2}}\right)+l\left(k_{1} \cdot \dot{4}^{F L_{2}}-k_{2} \cdot \dot{\Delta}_{2}^{F L_{2}}\right)$

$M_{F L_{2}} \cdot \ddot{\forall}_{F L_{2}}=k_{1} \cdot \Delta^{F L_{2}}+k_{2} \cdot \Delta_{2}^{F L_{2}}-F_{F R}\left(\operatorname{sign} \dot{4}^{F L_{2}}-\operatorname{sign} \dot{\Delta}_{2}^{F L_{2}}\right)$

$m_{i} \cdot\left(\ddot{x}_{F L_{1}}-\ddot{x}_{F L_{2}}\right)+\left(m_{i} \cdot z_{c i}\right) \cdot \ddot{\varphi}_{F L_{2}}=0$

$I_{i} \cdot \ddot{\varphi}_{F L_{2}}+\left(m_{i} \cdot z_{c i}\right) \cdot\left(\ddot{x}_{F L_{1}}-\ddot{x}_{F L_{2}}\right)-g \cdot\left(m_{i} \cdot z_{c i}\right) \cdot \varphi_{F L_{2}}=0$

$m_{i} \cdot \ddot{z}_{F L_{2}}=0$

where

$$
\Delta_{1}^{i}=z_{F L_{i}}-l \cdot \varphi_{F L_{i}} ; \Delta_{2}^{i}=z_{F L_{i}}+l \cdot \varphi_{F L_{i}}
$$

$M_{F L_{i}}^{\prime}$ is the gross mass of $i$-th section of the flat car; $M_{F L_{i}}$ is the mass of the carrying structure of $i$-th section of the flat car; $I_{F L_{i}}$ is the inertia moment of $i$-th section of the flat car; $P_{n}$ is the longitudinal force on the trailer; $l$ is half a base of a flat car section; $F_{F R}$ is the absolute value of the dry force in a spring group; $k_{1}, k_{2}$ are rigidities of springs in the spring groups of flat car bogies (an 18-100 bogie); $m_{i}$ is the container mass; $z_{c i}$ is the height of the container's mass center; $I_{i}$ is the inertia moment of $i$-th container; $x_{i}, \varphi_{i}, z_{i}$ are coordinates defining displacements of flat car sections relative to the corresponding axles.

The longitudinal force on the flat car carrying structure was taken 2.5 MN [18]. The differential equations were solved with the Runge-Kutta method in MathCad software [15, 16].

The results of the research made it possible to conclude that accelerations to the first section of the flat car carrying structure from the force were $36.4 \mathrm{~m} / \mathrm{s}^{2}$, and to the second section - about 37 $\mathrm{m} / \mathrm{s}^{2}$ (Fig. 10).

Besides the research into the dynamic loads on the articulated flat car carrying structure was conducted with computer modeling. The adequacy of the models designed was checked with an F-test. The results of the calculation showed that the hypothesis on adequacy was not rejected.

Numerical values of accelerations to the carrying structure of an articulated flat car with containers on under operational loading modes were used in the capacity research of the carrying structure as the dynamic loading components.
(A)

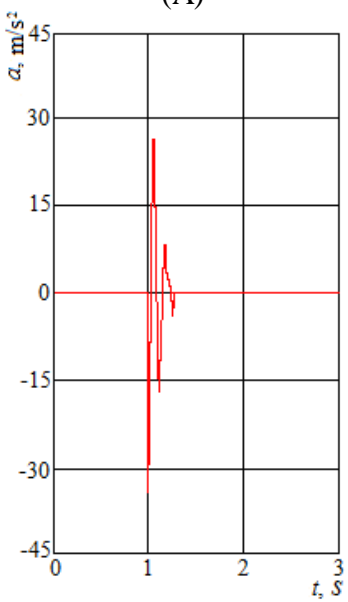

(B)

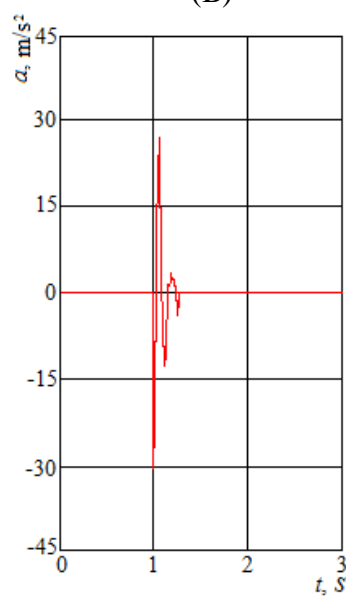

(C)

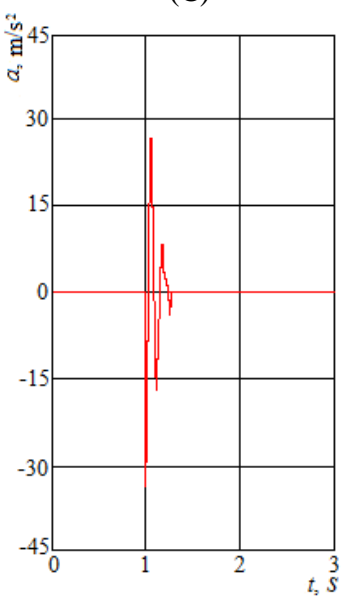

(D)

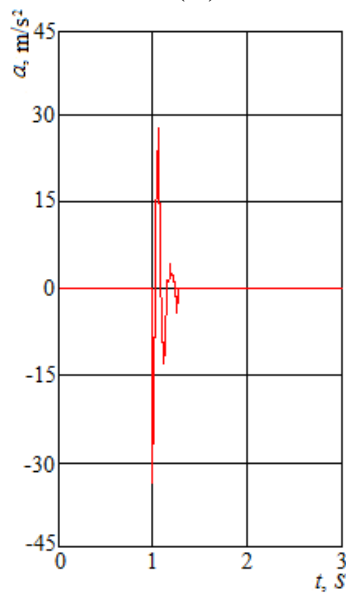

Fig. 10: Accelerations on the carrying structure of the articulated flat car with containers on at design mode I (stretch - jerk); (A) the first flat car section in terms of the longitudinal force; (B) a container placed on the first flat car section in terms of the longitudinal force; (C) the second flat car section in terms of the longitudinal force; (D) a container on the second flat car section in terms of the longitudinal force

The capacity research into an articulated flat car was done with the finite element method.

The capacity model of the articulated flat car carrying structure under design mode I (jerk - stretch) is given in Fig. 11.

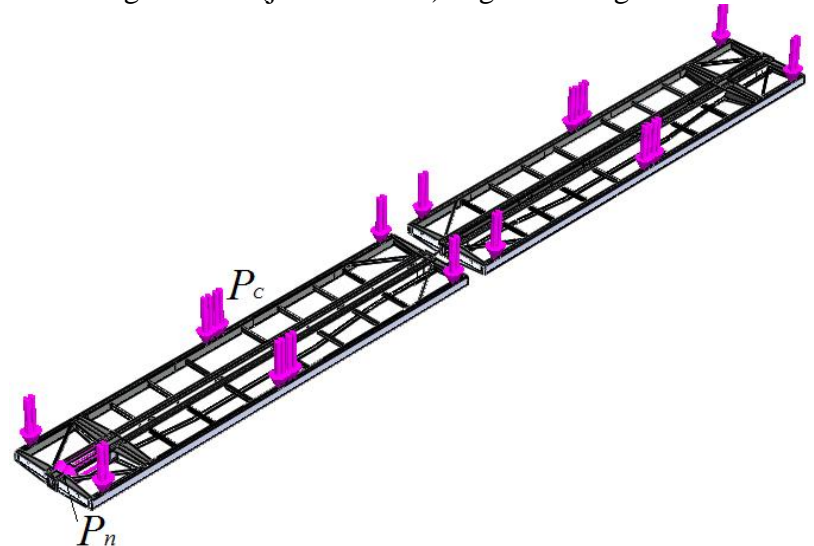

Fig. 11: Capacity model of the articulated flat car carrying structure under design mode I (jerk - stretch)

The capacity model considered both longitudinal force $P_{n}$ and vertical forces, in areas where the containers rested upon the fitting stops, $P_{C}$ impacting the flat car carrying structure.

The model was fixed in areas where the frame rested on the bogies.

The results of the calculation of the articulated flat car carrying structure under design mode I (jerk - stretch) are given in Fig. 12, 13 , and the numerical capacity values under the basic loading modes - in Table 2.

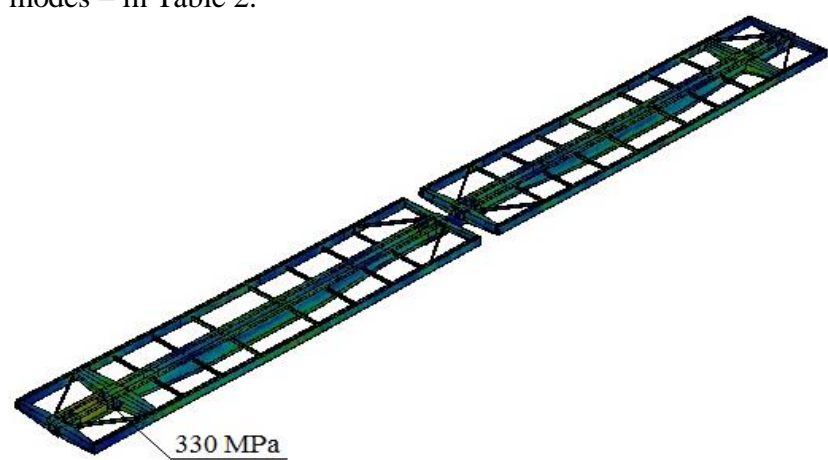

Fig. 12: Stress state of the articulated flat car carrying structure under design mode I (jerk - stretch) 


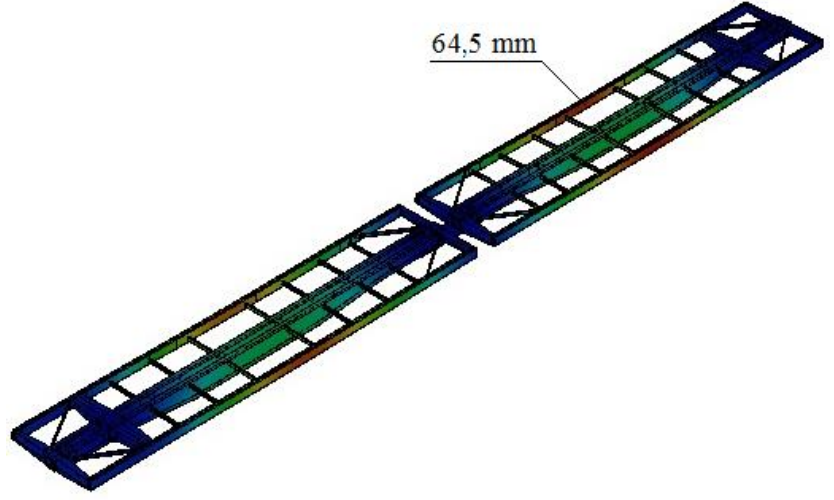

Fig. 13: Displacements in the nodes of the articulated flat car carrying structure under design mode I (jerk - stretch)

Table 2: The capacity indices of the articulated flat car carrying structure under the operational loading modes

\begin{tabular}{|c|c|c|c|c|}
\hline \multirow[b]{2}{*}{ Capacity index } & \multicolumn{4}{|c|}{ Loading mode } \\
\hline & 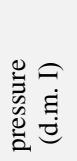 & 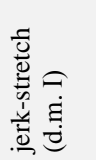 & 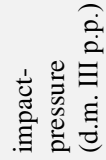 & 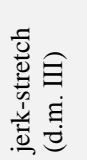 \\
\hline Stresses, MPa & 310.5 & 329.8 & 302.5 & 312.8 \\
\hline $\begin{array}{l}\text { Displacements in nodes, } \\
\mathrm{mm}\end{array}$ & 66.1 & 64.5 & 64.2 & 64.5 \\
\hline Deformations & $\begin{array}{l}\text { ro } \\
\dot{n} \\
0 \\
\text { ì }\end{array}$ & $\begin{array}{l}\text { Uo } \\
\dot{0} \\
\text { ปे } \\
\dot{0}\end{array}$ & $\begin{array}{l}\hat{0} \\
\dot{0} \\
0 \\
\dot{0}\end{array}$ & $\begin{array}{l}\hat{0} \\
\dot{\dot{d}} \\
\text { Oे } \\
\dot{\mathrm{N}}\end{array}$ \\
\hline
\end{tabular}

Table 2 demonstrates that the greatest tension was in design mode I (jerk - stretch), it is concentrated in the area of interaction between the bolster beam and the center sill and was about $330 \mathrm{MPa}$ (Fig. 12), but does not exceed the admissible value, the maximum displacements in the structure are in the middle part of the main longitudinal beams of the frame and account for $64.5 \mathrm{~mm}$ (Fig. 13), the deformations in the structure are $2,026 \cdot 10^{-2}$.

\section{Conclusion}

1. In order to improve the efficiency of container transportation the author proposes production of articulated flat cars based on typical structures;

2. The research into the dynamic loading on an articulated flat car with containers under train ferry transportation was done by applying mathematical and computer modeling. It was established that without displacements of the flat car and containers relative to the initial position, the general value of the acceleration on the outer (from the bulwark) flat car with containers was about $0.25 \mathrm{~g}$. With flat car displacements due to train ferry vibrations and immobility of the containers relative to the frame the general acceleration value was about $0.3 \mathrm{~g}$. With displacements of a flat car relative to the deck and containers relative to the flat car frame, the general acceleration value to the outer (from the bulwark) flat car was about $0.4 \mathrm{~g}$, and to the containers on it was about $0.47 \mathrm{~g}$; 3. The research into the dynamic loading on the articulated flat car with containers on under rail track operation was done with mathematical and computer modeling. It was established that accelerations on the first section in terms of the longitudinal force was about $2.5 \mathrm{~g}$, and on the second - about $2.8 \mathrm{~g}$ if the containers do not move relative to the frame;

4. The results of the capacity calculation for the carrying structure of a flat car showed that the maximum equivalent stresses do not exceed the accessible ones;

5. While designing new generation flat cars for transportation of removable transport units and containers, it is necessary to consider refined acceleration values which can impact them under both rail track operation and train ferry transportation; it will provide operational stability of their carrying structures along international transport corridors;

6 . The research conducted can enhance the efficiency of combined transportation along international transport corridors.

\section{References}

[1] Krason W, Niezgoda T, "Fe numerical tests of railway car for intermodal transport according to PN-EU standards", Bulletin of the Polish Academy of Sciences Technical Sciences, Vol. 62, No.4, (2014), pp. $843-851$

[2] Fomin O, "Improvement of upper bundling of side wall of gondola cars of 12-9745 model", Scientific and technical journal "Metallurgical and Mining Industry», No.1, (2015), pp. 45 - 48.

[3] Kelrykh M, Fomin O, "Perspective directions of planning carrying systems of gondolas", Scientific and technical journal «Metallurgical and Mining Industry», No.6, (2014), pp. $64-67$.

[4] Chlus K, Krason W, "Numerical standard tests of railway carriage platform", Journal of KONES Powertrain and Transport, Vol. 19, No.3, (2012), pp. $59-64$.

[5] Nader M, Sala M, Korzeb J, Kostrzewski J, "Kolejowy car transportowy jako nowatorskie, innowacyjne rozwiązanie konstrukcyjne do przewozu naczep siodłowych i zestawów drogowych dla transportu intermodalnego", Logistyka, No.4, (2014), pp. 2272 2279.

[6] Kozhokar KV, "Osobennosti razrabotki skorostnogo sochlenennogo vagona-platformyi dlya perevozki konteynerov", Transport Rossiyskoy Federatsii, No.3, (2013), pp. 21-24, (In Russian).

[7] Bondarenko AI, Panin AYu, "Teoreticheskaya i eksperimentalnaya otsenka prochnosti vagona-platformyi dlya perevozki avtomobilnyih polupritsepov", Transport Rossiyskoy Federatsii, No.3, (2014), pp.33-35, (In Russian)

[8] Lysikov N, Kovalev R, Mikheev G, "Stress load and durability analysis of railway vehicles using multibody approach", Transport problems, Vol. 2, No.3, (2007), pp. $49-56$.

[9] WBN Waggonbau Niesky GmbH: Developing a flexible platform of freight cars, Intern. Edition, No.1, pp. 46.

[10] Switching over to the home platform, J. for partners Transmashholding, No. 3, (2015), pp. $22-23$.

[11] Niezgoda T, Krasoń W, Stankiewicz M, "Simulations of motion of prototype railway car with rotatable loading floor carried out in MSC Adams software, J. of KONES”, Powertrain and Transport, Vol. 19, No.4, (2015), pp. 495-502.

[12] Lovska AO, "Udoskonalennya nesuchoyi konstruktsiyi vagonaplatformi dlya pidvischennya efektivnosti konteynernih perevezen", Nauka ta progres transportu. Visnik Dnipropetrovskogo natsionalnogo universitetu zaliznichnogo transportu, No.1 (67), (2017), pp. 168 - 183, (In Ukranian).

[13] Lovska AO, "Doslidzhennya dinamichnoyi navanta-zhenosti vagona-platformi z konteynerami pri perevezenni na zaliznichnomu poromi”, Zaliznichniy transport Ukrayini, No.2, (2017), pp.16 - 20, (In Ukranian).

[14] Lovska AO, "Viznachennya navantazhenosti kon-teyneriv u skladi kombinovanih poyizdiv pri perevezenni zaliznichnim poromom", Nauka ta progres transportu. Visnik Dnipropetrovskogo natsionalnogo universitetu zaliznichnogo transportu, No.6 (72), (2017), pp. $49-60$, (In Ukranian).

[15] Dyakonov V. MATHCAD 8/2000: spetsialnyiy spravochnik, SPb: Piter, (2000), pp: 392-411.

[16] Kiryanov DV, Mathcad 13, SPb.: BHV - Peterburg, (2006), pp: 254-308.

[17] Shadur LA, Koturanov VI, Hohlov AA, Anisimov PS, Konstruirovanie $i$ raschet vagonov, Moskva: UMK MPS Rossii, (2000), pp: 521-531.

[18] Vagonyi gruzovyie. Trebovaniya $k$ prochnosti $i$ dinamiche-skim kachestvam. GOST 33211-2014, M.: Standartinform, (2016), pp: $30-54$.

[19] Bogomaz GI, Mehov DD, Pilipchenko OP, Chernomashentseva YuG, "Nagruzhennost konteynerov-tsistern, raspolozhennyih na zheleznodorozhnoy platforme, pri udarah v avtostsepku", Zb. nauk. prats “Dinamika ta keruvannya ruhom mehanichnih sistem”. 1992, pp. 87 -95, (In Russian). 